\title{
Sevoflurane and isoflurane genotoxicity in kidney cells of mice
}

\author{
Gordana Brozović1,2, Nada Oršolić ${ }^{3}$, Ružica Rozgaj ${ }^{4}$, Fabijan Knežević ${ }^{5}$, Anica Horvat Knežević3, \\ Martina Maričić ${ }^{2}$, Dajana Krsnik ${ }^{3}$, and Vesna Benković 3
}

Faculty of Medicine, University of Osijek, Osijek , Department of Anaesthesiology, Reanimatology and ICU, University Hospital for Tumours, Sestre milosrdnice University Hospital Centre ${ }^{2}$, Division of Animal Physiology, Department of Biology, Faculty of Science, University of Zagreb3, Mutagenesis Unit, Institute for Medical Research and Occupational Health ${ }^{4}$, Department of Pathology, Sveti Duh University Hospital ${ }^{5}$, Zagreb, Croatia

[Received in January 2017; Similarity Check in January 2017; Accepted in August 2017]

The aim of this study was to evaluate the DNA damage and repair in kidney cells of Swiss albino mice after repeated exposure to sevoflurane and isoflurane and compare their detrimental effects. We used the alkaline comet assay to establish the genetic damage and measured three parameters: tail length, tail moment, and tail intensity of comets. These parameters were measured immediately after exposure to the above mentioned inhalation anaesthetics, two hours, six hours, and 24 hours later and were compared with the control group. Mean values of all three parameters were significantly higher in experimental groups compared to the control group. DNA damage in kidney cells of mice exposed to sevoflurane increased continuously before it reached its peak 24 hours after exposure. Isoflurane induced the highest DNA damage two hours after exposure. Levels of DNA damage recorded $24 \mathrm{~h}$ after cessation of exposure to both tested compounds suggest that sevoflurane was slightly more genotoxic than isoflurane to kidney cells of mice. According to these results, the currently used volatile anaesthetics sevoflurane and isoflurane are able to damage DNA in kidney cells of mice. Such findings suggest a possibility for similar outcomes in humans and that fact must be taken into account in everyday clinical practice.

KEY WORDS: alkaline comet assay; DNA repair; genetic damage; in vivo studies, volatile anaesthetics

The halogenated volatile anaesthetics sevoflurane and isoflurane are the most widely used volatile anaesthetics in clinical practice providing dose-dependent amnesia, sedation, and hypnosis sufficient for surgical procedures (1). These potent anaesthetics are liquids at room temperature and atmospheric pressure but they have propensity to move from liquid to gas phase due to their high vapour pressure (1). Although the mechanism of action of volatile anaesthetics is complex, likely involving numerous membrane proteins and ion channels, it is clear that producing their ultimate effect depends on the attainment of the therapeutic tissue concentration in the central nervous system (2). Because of the large pulmonary surface area, access to circulation is rapid, as are their pharmacologic effects. They are almost instantaneously absorbed through the respiratory epithelium and mucous membranes of the respiratory tract into the blood avoiding hepatic first pass metabolism (3).

Although volatile anaesthetics are delivered and primarily eliminated via lungs (3), they undergo oxidative metabolism by cytochrome P450 enzymes in the liver, kidney, and lungs. Isoflurane is metabolised to a lesser extent $(0.2 \%)$ than sevoflurane $(5 \%)$. Biotransformation

Correspondence to: Prof Vesna Benković, Division of Animal Physiology, Department of Biology, Faculty of Science, University of Zagreb, Rooseveltov trg 6, Zagreb, Croatia; vesna@biol.pmf.hr has a little effect on the pharmacologic activity of anaesthetics but it may have a significant effect on the toxicity of these agents (3). The metabolism of certain inhaled halogenated anaesthetics can produce inorganic fluoride that may be directly nephrotoxic (3). Sevoflurane metabolism results in the highest serum fluoride ion level of current anaesthetics. In spite of that, clinical signs of nephrotoxicity do not occur even when sevoflurane is administered for prolonged periods in low-flow breathing systems.

Comparing the genotoxicity of sevoflurane and isoflurane in patient's peripheral blood lymphocytes during and after anaesthesia using comet assay showed that both anaesthetics have a potent genotoxic effect. The effect is at its peak 120 minutes after anaesthesia and DNA repair activity starts on the third day after anaesthesia. It reaches its completion on the fifth day (4). Alleva et al. (5) investigated the genotoxicity of sevoflurane on DNA of peripheral lymphocytes immediately following anaesthesia and 24 hours after surgery. Genotoxicity was evaluated by assaying DNA damage, DNA repair enzyme activity, apoptosis and GSH (plasma glutathione) content in peripheral lymphocytes isolated from 20 patients undergoing orthopaedic surgery. DNA strand breaks occurred on the first post-operative day but 24 hours after the surgery most of the oxidised DNA bases were repaired. The comet assay 
was used to prove the potential genotoxicity of inhalation anaesthetics in human peripheral blood lymphocytes $(6,7)$. This simple method enables a sensitive detection of primary DNA damage in single eukaryotic cells (8). It presents several significant advantages over other commonly used genotoxicity assays. This assay has previously been formally validated in order to represent the standardised protocol with acceptability by international regulatory agencies (9).

The DNA injury estimated in peripheral blood lymphocytes during anaesthesia with sevoflurane and isoflurane demonstrated an increased mean comet migration at two hours following anaesthesia and the cells repaired completely on the fifth postoperative day (4). Sardas et al. (6) reported similar results with isoflurane anaesthesia. On the other hand, Szyfter et al. (7) concluded that sevoflurane did not have genotoxic effects both in vitro and in vivo. Furthermore, DNA damage of mouse cells, investigated by the alkaline comet assay and micronucleus test, was significant and none of the tested tissues showed signs of repair until 24 hours after the exposure to sevoflurane (10). Rozgaj et al. $(11,12)$ reported the genetic damage induced by anaesthetic gases in occupationally exposed population.

The existing knowledge regarding the nephrotoxic potential of sevoflurane and isoflurane is still incomplete. Most studies focused on functional renal impairments and nephrotoxicity but did not investigate the adverse effects at the cell level. The aim of our study was to highlight the genotoxic damage and repair in kidney cells of Swiss albino mice during the first 24 hours after repeated exposure to sevoflurane and isoflurane and to compare their detrimental effects using the alkaline comet assay.

\section{MATERIALS AND METHODS}

\section{Animal studies and experimental procedure}

The animal study was designed in accordance with the relevant Croatian guidelines: Animal Protection Act (13) and the Ordinance on the protection of animals used for scientific purposes (14). It was also approved by the Ethical Committee of the Faculty of Science and Medical School (University of Zagreb, Croatia).

Inhalation anaesthetic sevoflurane (1-chloro-2,2,2trifluoroethyl difluoromethyl ether, $\mathrm{CHF}_{2} \mathrm{OCHClCF}_{3}$; Sevorane) and isoflurane (iso-1,1,1,3,3,3-hexafluoropropyl fluoromethyl ether, $\left.\mathrm{CH}_{2} \mathrm{FOCH}\left[\mathrm{CF}_{3}\right]_{2}\right)$; Forane) were provided by Abbott Laboratories LTD (Queenborough, UK). A total of 45 Swiss albino male mice (three months old, body weight approximately 20-25 grams) were obtained from the breeding unit of the Department of Biology, Faculty of Science, University of Zagreb, Croatia. The animals were housed at $22 \pm 1^{\circ} \mathrm{C}$ and $50-70 \%$ humidity with a $12 / 12$ hours light/dark cycle photoperiod. They were receiving standard laboratory diet (4 RF 21, Mucedola s.r.l., Italy) and water ad libitum.
Anaesthesia was maintained with sevoflurane $(2.4 \mathrm{vol} \%)$ or isoflurane $(1.7 \mathrm{vol} \%)$ in a continuous flow of a 50:50 mixture of oxygen and air $\left(3 \mathrm{~L} \mathrm{~min}^{-1}\right)$ in a specially designed induction chamber connected to an anaesthetic machine (Sulla 800; Dräger) using a compatible evaporator. The fresh gas was flowing in one direction, without rebreathing and exhaled gases were released through the exhaust pipe into the atmosphere. Nitrous oxide was not used in anaesthesia in order to avoid additional DNA lesions. The depth of anaesthesia was considered satisfactory when mice were sleeping calmly, breathing spontaneously, and not wiggling their tail.

The animals were divided into eight experimental groups and corresponding non-treated controls. Each group consisted of five mice. Experimental groups of mice were exposed to sevoflurane (2.4 vol \%) or isoflurane (1.7 vol \%) during two hours for three consecutive days. Following termination of exposure, mice were sacrificed by cervical dislocation at four time points: immediately after administration of third anaesthesia $(0 \mathrm{~h})$, and two, six, and $24 \mathrm{~h}$ afterwards. Kidneys were dissected and samples of cells were collected for further analysis.

If not specified, chemicals and reagents were purchased form from Sigma-Aldrich Chemical Co. (St. Louis, MO, USA).

\section{The comet assay}

Kidney tissues were collected, minced, and passed through a stainless steel mash and single-cell suspensions were made in the homogenisation buffer solution cooled to $4{ }^{\circ} \mathrm{C}(0.075 \mathrm{M} \mathrm{NaCl}$ and 0.024 $\mathrm{M} \mathrm{Na}$ EDTA; $\mathrm{pH}$ 7.5), at the ratio $1 \mathrm{~g}$ tissue $/ 1 \mathrm{~mL}$ buffer). The comet assay was carried out under alkaline conditions, as described by Singh et al. (15). Two slides per animal were prepared. Agarose gels were prepared on fully frosted slides coated with $1 \%$ and $0.6 \%$ normal melting point (NMP) agarose (Sigma). Six microliters of freshly prepared kidney cell suspensions were mixed with $0.5 \%$ low melting point (LMP) agarose (Sigma) placed onto precleared microscope slides and covered with $0.5 \%$ LMP agarose. The slides were immersed for two hours in a freshly prepared ice-cold lysis solution (2.5 M NaCl, 100 mM Na EDTA, $10 \mathrm{mM}$ Tris-HCl, $1 \%$ sodium sarcosinate (Sigma), pH 10, with $1 \%$ Triton X-100 (Sigma) and $10 \%$ dimethyl sulfoxide (Kemika, Zagreb, Croatia). Denaturation and electrophoresis were carried out at $4{ }^{\circ} \mathrm{C}$ under dimmed light in a freshly prepared electrophoresis solution ( $300 \mathrm{mM} \mathrm{NaOH}, 1 \mathrm{mM} \mathrm{Na}{ }_{2}$ EDTA, $\mathrm{pH}$ 13). After $20 \mathrm{~min}$ of denaturation, the slides were randomly placed in a horizontal gel-electrophoresis unit, facing the anode. After the unwinding of DNA, electrophoresis was carried out in the alkaline solution for $20 \mathrm{~min}$ at $25 \mathrm{~V}(300 \mathrm{~mA})$. Electrophoresis at high $\mathrm{pH}$ results in structures resembling comets, as observed by fluorescence microscopy; the intensity of the comet tail relative to the head reflects the number of DNA breaks. After 
electrophoresis, the slides were neutralised by adding Tris buffer (0.4 M Tris-HCl, $\mathrm{pH} 7.5)$ three times at five minute intervals. Images of 100 randomly selected cells ( 50 counts on each duplicate slide) were analysed for each sample (animal). The slides were stained with ethidium bromide $\left(20 \mu \mathrm{g} \mathrm{mL}^{-1}\right)$ and examined under magnification 250x, using an epifluorescence microscope (Leitz, Germany). The microscope was connected through a camera to a computerbased image analysis system (Comet Assay IV software, Perspective Instruments Ltd., Suffolk, UK). A total of 500 kidney cells from each group were analysed. Comets were randomly captured at a constant depth of the gel, avoiding the edges of the gel, occasional death cells, and superimposed comets. Comet analysis was performed on coded slides by one reader to avoid variability due to subjective scoring. DNA damage was determined as the tail length (distance of DNA migration from the centre of the body of the nuclear core, expressed in $\mu \mathrm{m}$ ), tail intensity (percentage of genomic DNA that migrated during the electrophoresis from the nuclear core to the tail), and tail moment (product of the tail length and the fraction of total DNA in the tail).

\section{Statistical analysis}

Statistical analysis was performed by using Statistica 5.0 software (Statsoft, Tulsa, USA). Descriptive statistics was calculated. Analysis of variance (ANOVA) was selected for testing the effects of sevoflurane and isoflurane. The data obtained with the alkaline comet assay were first logarithmically transformed to normalise the distribution and equalise variances. Multiple comparisons between groups were tested using a post-hoc Tukey honest significant difference (HSD) test. The level of statistical significance was set at $\mathrm{P}<0.05$.

\section{RESULTS}

Results regarding the primary DNA damage levels in kidney cells of mice measured by the alkaline comet assay and detailed explanations of their statistical significance are presented in Table 1. The values of all comet parameters measured in kidney cells observed immediately after the last exposure to sevoflurane showed that the DNA damage was minor and not significantly increased in comparison with the control group. However, the values recorded at the time-points two hours, six hours, and $24 \mathrm{~h}$ after cessation of sevoflurane exposure suggest a clear genotoxic effect of the tested compound. In all experimental groups, DNA damage levels in kidney cells were significantly different $(\mathrm{P}<0.05)$ vs. control group.

All isoflurane exposed groups revealed a statistically significant $(\mathrm{P}<0.05)$ increase of comet parameter values compared to control. Contrary to sevoflurane, the repeated exposure to isoflurane immediately caused a significant increase in the comet parameters values and the highest level of primary DNA damage was measured two hours after the treatment. After six and 24 hours, DNA damage in kidney cells exposed to isoflurane slowly decreased but it did not return to the level of the control group.

It is noteworthy to mention that the level of primary DNA damage in kidney cells of isoflurane-exposed mice two hours after the treatment cessation was almost four-fold higher compared to the DNA damage observed in rats given sevoflurane treatment (Table 1), which was statistically significant.

However, the values recorded $24 \mathrm{~h}$ after the cessation of exposure to both tested compounds suggest that sevoflurane was slightly more genotoxic than isoflurane to kidney cells of mice, which is supported by higher values of all three studied comet parameters.

Taken together, our comet assay results suggest a possibility that sevoflurane should be considered a more potent inducer of more complex DNA damage, whose repair took more than $24 \mathrm{~h}$, while isoflurane caused immediate increase of simple forms of DNA, which was mostly repaired within the first six hours after the cessation of exposure.

\section{DISCUSSION}

In spite of the extensive research conducted so far, both in vivo on animal models or in clinical studies with patients anaesthetised with sevoflurane and isoflurane, toxicity profiles of these compounds remain controversial. The present study intended to fill the existing gap in the knowledge by adding information on the levels of primary DNA lesions detected in the mice kidney following exposure to these frequently used inhalation anaesthetics. In comparison with previous studies, which mostly focused on functional renal impairments and nephrotoxicity (16-20), here we studied the level of primary DNA damage in single kidney cells. Taking into account that the majority of primary DNA lesions detectable using the alkaline comet assay are potentially repairable, our results mostly indicate the acute effects caused by the tested compounds, and also suggest the differences in their ability to destabilise the integrity of DNA in kidney cells of mice. It is noteworthy to mention here that the alkaline comet assay we used allows a sensitive detection of different forms of primary DNA damage in single cells but the most important among them are DNA strand breaks and alkali-labile sites (8, 21-23).

According to our results, both tested compounds were able to induce primary DNA damage in kidney cells of Swiss albino mice detectable using the alkaline comet assay. What we clearly showed was that sevoflurane and isoflurane differed in their capacities to produce measurable DNA damage and that their repair dynamics differed as well. It has to be mentioned that primary DNA damage measured in kidney cells after either treatment did not return to the values measured in the control group. Thus, 24 hours was 


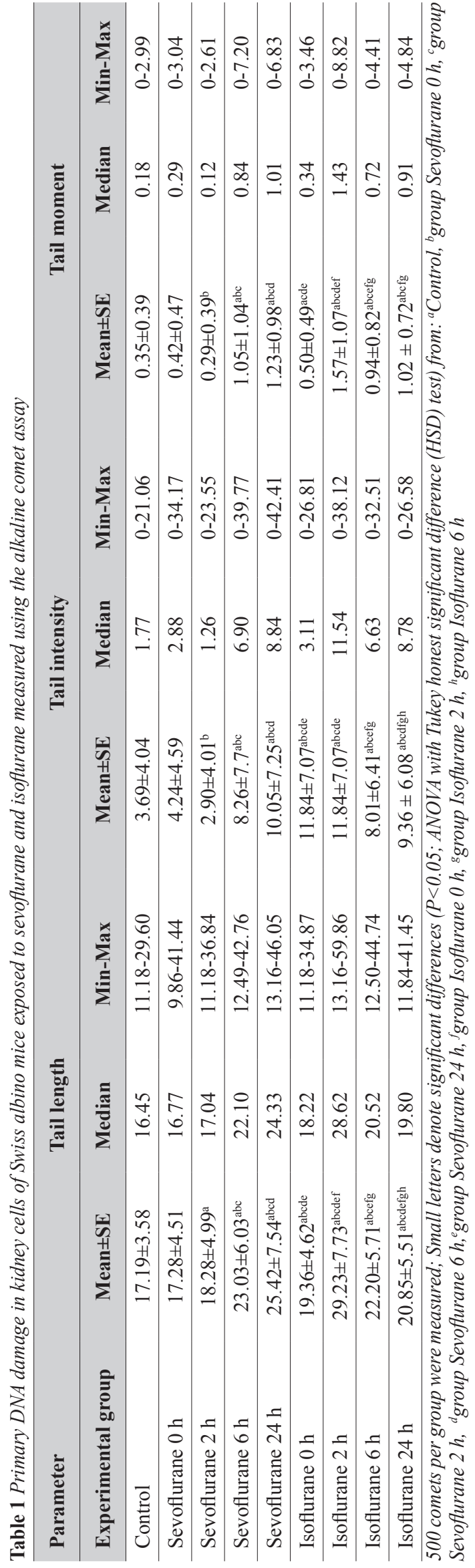

not long enough time to remove all the lesions inflicted by both treatments in DNA.

It is interesting to stress here that when tail length parameter was taken into account, sevoflurane exposure caused a steadily increase in DNA damage across the time points studied. Isoflurane exposure, on the other hand, resulted in the maximum tail length measured at time point two hours, which decreased at later time points. However, when tail intensities were taken into account, sevoflurane treatment resulted in a significant drop of DNA content in comet tails two hours after exposure cessation (which was even lower than in the control), while later on this value continued to increase. Isoflurane exposure, in contrast, did not result in such immense drop of the DNA content in comet tails at the same time point.

Such findings emphasise the need for a concurrent evaluation of the tail length and tail intensity parameters to prevent erroneous conclusions regarding the overall primary DNA damage measured by the comet assay. If our conclusions were based only on the tail length, one could overlook the time point, which was an important element for the repair of sevoflurane induced primary DNA damage.

A detailed analysis, which included both tail length and tail intensity, showed that during the post-exposure time the amount of DNA breaks induced by complex repair processes in kidney cells of sevoflurane-treated mice increased. This was obviously due to the formation of additional breaks in DNA, which was subjected to repair processes. These breaks represent an indirect DNA damage, which contributes to the overall increase in comet tail parameters.

Different DNA damage levels measured by the alkaline comet assay after sevoflurane and isoflurane exposure could be the result of several issues. Among these, the most important are their availability, lipid solubility, stability, biotransformation/metabolism, and different capability to produce oxidative stress. As known, sevoflurane undergoes much more extensive metabolism than isoflurane (24), which evidently contributed to the amount of reactive compounds with DNA damaging properties. Previous studies suggest that in humans $2-5 \%$ of the absorbed dose of sevoflurane is metabolised, compared to only 0.2 to $2 \%$ of isoflurane $(3,25)$. Second, it is important to mention that sevoflurane biotransformation results in the formation of inorganic fluoride and the so-called compound A, which are both considered toxic and, especially, nephrotoxic (25, 26). Goldberg et al. (27) found that sevoflurane biotransformation resulted in the generation of greater amounts of fluoride ions than isoflurane. As known, sevoflurane metabolism occurs predominantly in the liver by cytochrome P450 2E1 isoenzyme (3) but its extrahepatic metabolism is also present, which strongly influenced its nephrotoxicity (19). Sevoflurane metabolism is also associated with the formation of reactive products, which could directly trigger the generation of peroxynitrite and increase peroxides and nitric oxide (3). Its genotoxicity has 
been previously related to the generation of reactive oxygen species (28). Another important fact, which has to be mentioned, is that compound A may be an alkylating agent $(4,17)$. This could explain why we observed an increase in damage levels using the alkaline comet assay at time points six and $24 \mathrm{~h}$, considering that DNA lesions induced by the alkylating agents in general require the involvement of more complex repair systems $(29,30)$, than the "simple" types of DNA damage as strand breaks or alkali labile sites, which are usually repaired within few hours after infliction.

A limited number of studies has investigated DNA damage in lymphocytes, brain, liver, and kidney cells of animals repeatedly exposed to sevoflurane (31). Although sevoflurane was able to induce genetic lesions in vivo, the DNA damage seems to be repaired within the upcoming days of the last exposure. These studies have used different animal models and species, different times of exposure and routes, different doses and different time points besides a variety of other possible confounding factors such as temperature, hemodynamic data, and air flow rate, making the comparison among the reports very difficult (31). Furthermore, our previous study evaluated genetic damage in leukocytes, in the liver, kidney, and brain cells in vivo $(10,32)$ but none of the observed tissues revealed signs of repair until $24 \mathrm{~h}$ after the exposure to sevoflurane (32).

Isoflurane was in previous studies mostly reported not as toxic as sevoflurane and possessing much lower nephrotoxic potential, while the reports regarding its genotoxicity are controversial. Sardas et al. (6) studied the levels of DNA damage in patients anesthetised with isoflurane and observed slight genotoxic effects in lymphocytes, which effectively repaired within five days following exposure. Kim et al. (24) in their comet assay study reported that isoflurane exposure resulted in significant DNA damage in lymphocytes, bone marrow, spleen, brain, liver, and lung of rats. Although in rats exposed to isoflurane for $60 \mathrm{~min}$ an increase in oxidative stress parameters such as lipid and protein oxidation was observed, the authors could not show evidence of the association between DNA damage and oxidative stress parameters. According to Braz et al. (33), exposure of patients to isoflurane did not induce genotoxicity and cytotoxicity in lymphocytes and in their leukocytes, although genetic repair and apoptosis-related genes were down-regulated on the first post-operative day (33).

Taken together, we presume that different levels of DNA damage in kidney cells could be related both to direct action of the tested compounds on DNA but also to different level of oxidative stress caused by the treatment. In this view, sevoflurane seems to be a more effective producer of oxidative stress than isoflurane. In sevoflurane treated human leukocytes, a dose-dependent oxidative stress and cellular injury, especially apoptosis, were observed (28, 34). Rocha et al. (35) provided evidence that sevoflurane induced genetic damage, whereas isoflurane increased systemic antioxidative status in Wistar rats exposed for
$120 \mathrm{~min}$. They suggest that possible mechanisms of sevoflurane genotoxicity include direct genotoxicity and/ or oxidative route by metabolism (35). Clinical studies indicated the absence of systemic DNA damage or oxidative DNA damage in patients under isoflurane anaesthesia (33). In patients undergoing minimally invasive surgery under isoflurane anaesthesia, a slight increase in the plasma's antioxidant capacity was observed (33). A positive effect of isoflurane in the protection of cardiomyocytes from damage by oxidative stress has also been proven by Marinovic et al. (36). These authors underscore the importance of sarcolemmal and mitochondrial adenosine ariphosphate- (ATP-) sensitive potassium channels in the protection. Hirata et al. (37) proved that isoflurane reduced myocardial infarction size by modulating mitochondrial ROS at clinical concentrations. Rocha et al. (35) showed that rats anesthetised with isoflurane had a higher plasma antioxidative status. Concerning these findings, we presume that repair of DNA in rats treated with isoflurane in our study could be the consequence of the activation of antioxidative mechanisms in kidney cells.

A few limitations of our approach also merit comment. One of the limitations is the selection of exposure design. Such exposure design was possible to be established in an experiment on the rodent model but it is less likely that in the real situation patients would be subjected to three operative procedures day after day. Nevertheless, extreme life-threatening situations may lead to a similar scenario. Furthermore, the results obtained on the animal model cannot be always automatically extrapolated to the human model. Thus, our results represent a good indicator of possible outcomes of the exposure to tested anaesthetics but they have to be used with precaution since not all features of rat and human organisms are the same.

What also our comet assay results indicate is that amount of DNA damage measured in kidney cells $24 \mathrm{~h}$ after the termination of exposure to both tested compounds was similar if one looks at the median values of the tail intensity parameter. This parameter is generally the most important one for interpreting the comet assay results. We found that at time point $24 \mathrm{~h}$, the median values of tail intensity in rats exposed to both tested compounds were near $9 \%$ of DNA in the comet tail. This information is important from the view of prediction of potential risks associated with the exposure to both anaesthetics. We assume that these risks were relatively low, taking into account that the existing literature on the interpretation of the comet assay results suggests that tail intensity of up to $10 \%$ is tolerated even in the control cells subjected to the alkaline comet assay (8).

Our results also agree well with the results by Ruxanda et al. (20) who evaluated the effects of isoflurane and sevoflurane anaesthesia on the kidney structure and function in rats and did not find any signs of severe impairments of the kidney function. Similar results in elderly patients subjected to isoflurane and sevoflurane anaesthesia were 
reported by Hase et al. (26). Therefore, it seems that DNA damage inflicted following exposure to both anaesthetics was of transient nature, and it is obviously present in the first hours post exposure but is mostly effectively repaired later on, without producing severe functional impairments.

Although both tested compounds are in regular use in clinical practice, there is a constant need to broaden the knowledge on their potential adverse effects, by taking into account that the choice of the endpoint used in toxicity evaluation also influenced the outcomes observed. Thus, the development and refinement of sensitive methods and biomarkers at DNA level speak in favour of conducting new assessments of the adverse effects of substances which are in regular clinical use. In the case of sevoflurane and isoflurane, it is particularly important to extend the research, since the results of the existing studies are rather controversial.

There are various confounding factors that must be evaluated before assessing the risk of volatile anaesthetics to humans. Species variations in drug metabolism and toxicity, different exposure times and dosages, the flow rate (in air or in oxygen), and hypoxia during research procedure are some of the important factors that make it very complicated to extrapolate accurate conclusions from one species to another from in vivo investigations to humans (31). Regarding in vivo studies, results depend on different experimental designs, the type and duration of surgery, the characteristics of patients (age, physical status, associated co-morbidities or diseases, and other drugs used during the aesthetical procedure) (38).

Considering these facts, the foreknowledge that the currently used volatile anaesthetics are able to damage DNA in a number of genotoxic and mutagenic testes should be considered when calculating the value of the overall toxicity of these agents in human population.

In spite of the fact that genotoxicity of sevoflurane and isoflurane and their possible mechanisms of action have been proposed, much remains to be investigated. It is important to know that the protocols used for anaesthesia are quite different, making the conclusions and comparisons challenging. It is necessary to take into account the interference of the anaesthetics with cellular signal pathways, gene expression profiles, and genetic mechanisms to understand the mechanisms by which volatile anaesthetics induce DNA damage. Investigation of the oxidative stress mechanism and extension of the time of the study could provide new evidence of DNA cells damage during anaesthesia protocols, not only for sevoflurane and isoflurane but also for other commonly used anaesthetics. Therefore, this topic represents an area that is worth exploring further.

\section{REFERENCES}

1. Ebert TJ, Lindenbaum L. Clinical pharmacology of inhaled anesthetics. In: Evers AS, Maze M, Kharasch ED, editors.
Anesthetic pharmacology: basic principles and clinical practice. $2^{\text {nd }}$ ed. Cambridge: Cambridge University Press; 2011. p. 397-420.

2. Butterworth JF, Mackey DC, Wasnick JD. Inhalation anesthetics. In: Butterworth JF, Mackey DC, Wasnick JD, editors. Morgan \& Mikhail's clinical anesthesiology. $5^{\text {th }}$ ed. New York: McGraw-Hill Medical; 2013. p. 153-74.

3. Martin Jr. JL, Njoku DB. Metabolism and toxicity of modern inhaled anesthetics. In: Miller's anesthesia. $6^{\text {th }}$ ed. Philadelphia: Elsevier; 2005. p. 231-72.

4. Karabiyik L, Sardas S, Polat U, Kocaba S NA, Karakaya AE. Comparison of genotoxicity of sevoflurane and isoflurane in human lymphocytes studied in vivo using the comet assay. Mutat Res 2001;492:99-107. doi: 10.1016/S13835718(01)00159-0

5. Alleva R, Tomasetti M, Solenghi MD, Stagni F, Gamberini F, Bassi A, Fornasari PM, Fanelli G, Borghi B. Lymphocyte DNA damage precedes DNA repair or cell death after orthopaedic surgery under general anesthesia. Mutagenesis 2003;18:423-8. doi: 10.1093/mutage/geg013

6. Sardas S, Karabiyik L, Aygün N, Karakaya AE. DNA damage evaluated by the alkaline comet assay in lymphocytes of humans anaesthetized with isoflurane. Mutat Res 1998;418:16. doi: 10.1016/S1383-5718(98)00099-0

7. Szyfter K, Szulc R, Mikstacki A, Stachecki I, Rydzanicz M, Jałoszyński P. Genotoxicity of inhalation anaesthetics: DNA lesions generated by sevoflurane in vitro and in vivo. J Appl Genet 2004;45:369-74. PMID: 15306730

8. Collins AR. The comet assay for DNA damage and repair: principles, applications and limitations. Mol Biotechnol 2004;26:249-61. doi: 10.1385/MB:26:3:249

9. Uno Y, Kojima H, Omori T, Corvi J, Honma M, Schechtman LM, Tice RR, Beevers C, De Boeck M, Burlinson B, Hobbs CA, Kitamoto S, Kraynak AR, McNamee J, Nakagawa Y, Pant K, Plappert-Helbig U, Priestley C, Takasawa H, Wada K, Wirnitzer U, Asano N, Escobar PA, Lovell D, Morita T, Nakajima M, Ohno Y, Hayashi M. JaCVAM-organized international validation study of the in vivo rodent alkaline comet assay for detection of genotoxic carcinogens: II. Summary of definitive validation study results. Mutat Res Genet Toxicol Environ Mutagen 2015;786-788:45-76. doi: 10.1016/j.mrgentox.2015.04.010

10. Brozović G, Oršolić N, Rozgaj R, Kašuba V, Knežević F, Horvat Knežević A, Benković V, Lisičić D, Borojević N, Đikic D. DNA damage and repair after exposure to sevoflurane in vivo, evaluated in Swiss albino mice by the alkaline comet assay and micronucleus test. J Appl Genet 2010;51:79-86. doi: 10.1007/BF03195714

11. Rozgaj R, Kašuba V, Perić M. Chromosome aberrations in operating room personnel. Am J Ind Med 1999;35:642-6. doi: 10.1002/(SICI)1097-0274(199906)35:6<642::AIDAJIM11>3.0.CO;2-N

12. Rozgaj R, Kašuba V, Brozović G, Jazbec A. Genotoxic effects of anaesthetics in operating theatre personnel evaluated by the comet assay and micronucleus test. Int J Hyg Environ Health 2009;212:11-7. doi: 10.1016/j.ijheh.2007.09.001

13. Zakon o zaštiti životinja [Animal protection act, in Croatian]. Narodne novine 135/2006.

14. Pravilnik o zaštiti životinja koje se koriste u znanstvene svrhe [Ordinance on the protection of animals used for scientific purposes, in Croatian]. Narodne novine 55/2013. 
15. Singh NP, McCoy MT, Tice RR, Schneider EL. A simple technique for quantitation of low levels of DNA damage in individual cells. Exp Cell Res 1988;175:184-91. doi: 10.1016/0014-4827(88)90265-0

16. Martis L, Lynch S, Napoli MD, Woods EF. Biotransformation of sevoflurane in dogs and rats. Anesth Analg 1981;60:18691. doi: 10.1213/00000539-198104000-00003

17. Martin JL, Kandel L, Laster MJ, Kerschmann RL, Eger II EI. Studies of the mechanism of nephrotoxicity of compound A in rats. J Anesth 1997;11:32-7. doi: 10.1007/BF02480002

18. Caroline R, Stabernack MD, Edmond I, Eger II MD, Uwe H, Warnken MD, Harald Förster MD, Douglas K, Hanks MD, Linda D, Ferrell MD. Sevoflurane degradation by carbon dioxide absorbents may produce more than one nephrotoxic compound in rats. Can J Anesth 2003;50:249-52. doi: 10.1007/BF03017793

19. Erdem N, Kanbak M, Saricaoğlu F, Öcal T, Tanyel C, Ertas N, Berkkan A, Aypar Ü. Extrahepatic metabolism and renal effects of sevoflurane in a case of liver transplantation. Transplant Proc 2006;38:1463-6. doi: 10.1016/j. transproceed.2006.02.075

20. Ruxanda F, Miclaus V, Rus V, Gal AF, Oana L. Impact of isoflurane and sevoflurane anesthesia on kidney structure and function in rats. Bull UASVM Vet Med 2014;71(2). doi: 10.15835/buasvmen-vm:10388

21. Rojas E, Lopez MC, Valverde M. Single cell gel electrophoresis assay: methodology and applications. J Chromatogr B Biomed Sci Appl 1999;722:225-54. doi: 10.1016/S0378-4347(98)00313-2

22. Tice RR, Agurell E, Anderson D, Burlinson B, Hartmann A, Kobayashi H, Miyamae Y, Rojas E, Ryu J-C, Sasaki YF. Single cell gel/comet assay: guidelines for in vitro and in vivo genetic toxicology testing. Environ Mol Mutagen $2000 ; 35: 206-21$. doi: 10.1002/(S ICI) 1098 2280(2000)35:3<206::AID-EM8>3.0.CO;2-J

23. Azqueta A, Slyskova J, Langie SA, O’Neill Gaivão I, Collins A. Comet assay to measure DNA repair: approach and applications. Front Genet 2014;5:288. doi: 10.3389/ fgene.2014.00288

24. Kim H, Oh E, Im H, Mun J, Yang M, Khim JY, Lee E, Lim $\mathrm{SH}$, Kong MH, Lee M, Sul D. Oxidative damages in the DNA, lipids, and proteins of rats exposed to isofluranes and alcohols. Toxicology 2006;220:169-78. doi: 10.1016/j. tox.2005.12.010

25. Behne M, Wilke HJ, Harder S. Clinical pharmacokinetics of sevoflurane. Clin Pharmacokinet 1999;36:13-26. doi: 10.2165/00003088-199936010-00002

26. Hase K, Meguro K, Nakamura T. Effects of sevoflurane anesthesia combined with epidural block on renal function in the elderly: comparison with isoflurane. J Anesth 2000;14:53-60. doi: 10.1007/s005400050067

27. Goldberg ME, Cantillo J, Larijani GE, Torjman M, Vekeman D, Schieren H. Sevoflurane versus isoflurane for maintenance of anesthesia: are serum inorganic fluoride ion concentrations of concern? Anesth Analg 1996;82:1268-72. doi: 10.1097/00000539-199606000-00029

28. Wong CH, Liv TZ, Chve SM, Lu FJ, Liu YC, Lin ZC, Chen $\mathrm{CH}$. Sevoflurane-induced oxidative stress and cellular injury in human peripheral polymorphonuclear neutrophils. Food Chem Toxicol 2006;44:1399-407. doi: 10.1016/j. fct.2006.03.004

29. Bouziane M, Miao F, Ye N, Holmquist G, Chyzak G, O'Connor TR. Repair of DNA alkylation damage. Acta Biochim Pol 1998;45:191-202. PMID: 9701511

30. Kondo N, Takahashi A, Ono K, Ohnishi T. DNA damage induced by alkylating agents and repair pathways. J Nucleic Acids 2010;2010:543531. doi: 10.4061/2010/543531

31. Braz MG, Karahalil B. Genotoxicity of anesthetics evaluated in vivo (animals). Biomed Res Int 2015;2015:280802. doi: $10.1155 / 2015 / 280802$

32. Brozović G, Oršolić N, Knežević F, Horvat Knežević A, Benković V, Vrdoljak DV, Šarić A. Evaluation of DNA damage in vivo induced by combined application of cisplatin and sevoflurane. Eur J Anaesthesiol 2008;25:642-7. doi: $10.1017 / \mathrm{S} 0265021508004171$

33. Braz MG, Braz LG, Barbosa BS, Giacobino J, Orosz JE, Salvadori DMF, Braz JRC. DNA damage in patients who underwent minimally invasive surgery under inhalation or intravenous anesthesia. Mutat Res 2011;726:251-4. doi: 10.1016/j.mrgentox.2011.09.007

34. Matsuoka H, Kurosawa S, Horinouchi T, Kato M, Hashimoto Y. Inhalation anesthetics induce apoptosis in normal peripheral lymphocytes in vitro. Anesthesiology 2001;95:1467-72. doi: 10.1097/00000542-200112000-00028

35. Rocha TL, Dias-Junior CA, Possomato-Vieira JS, GonçalvesRizzi VH, Nogueira FR, de Souza KM, Braz LG, Braz MG. Sevoflurane induces DNA damage whereas isoflurane leads to higher antioxidative status in anesthetized rats. Biomed Res Int 2015;2015:264971. doi: 10.1155/2015/264971

36. Marinović J, Bošnjak ZJ, Stadnicka A. Distinct roles for sarcolemmal and mitochondrial adenosine triphosphatesensitive potassium channels in isoflurane-induced protection against oxidative stress. Anesthesiology 2006;105:98-104. PMID: 16810000

37. Hirata YH, Shim D, Pravdic D, Lohr NL, Pratt PF Jr, Weihrauch D, Kersten JR, Warltier DC, Bošnjak ZJ, Bienengraeber M. Isoflurane differentially modulates mitochondrial reactive oxygen species production via forward versus reverse electron transport flow: implications for preconditioning. Anesthesiology 2011;115:531-40. doi: 10.1097/ALN.0b013e31822a2316

38. Braz MG, Mazoti MA, Giacobino J, Braz LG, Golim MdeA, Ferrasi AC, de Carvalho LR, Braz JR, Salvadori DM. Genotoxicity, cytotoxicity and gene expression in patients undergoing elective surgery under isoflurane anaesthesia. Mutagenesis 2011;26:415-20. doi: 10.1093/mutage/geq109 


\section{Genotoksičnost sevoflurana i izoflurana u bubrežnim stanicama miševa}

Cilj ovog istraživanja bio je utvrditi razine oštećenja i oporavak DNA u bubrežnim stanicama Swiss albino miševa nakon ponavljanog izlaganja sevofluranu i izofluranu te usporediti genotoksičnost spomenutih anestetika. Razine oštećenja DNA procijenjene su metodom alkalnoga komet-testa, u kojem su kao pokazatelji oštećenja DNA korištena sljedeća tri parametra: dužina repa kometa, intenzitet repa i repni moment. Uzorci bubrežnog tkiva miševa uzimani su netom nakon izlaganja pojedinom inhalacijskom anestetiku, dva sata, šest sati i 24 sata poslije izlaganja. Dobiveni rezultati uspoređeni su s vrijednostima izmjerenima u kontrolnim, neizloženim jedinkama. Srednje vrijednosti svih triju parametara izmjerene u svim eksperimentalnim skupinama bile su statistički značajno veće u odnosu na kontrolnu skupinu. Razina primarnih oštećenja DNA u bubrežnim stanicama miševa izloženih sevofluranu kontinuirano se povećavala unutar 24 sata od izlaganja, za razliku od oštećenja koja su nastala nakon izlaganja izofluranu. Izofluran je uzrokovao najvišu razinu primarnih oštećenja DNA u bubrežnim stanicama dva sata nakon izlaganja, a nakon toga zamijećen je pad razine oštećenja DNA, koji upućuje na njihov učinkovit popravak. Međutim, niti nakon 24 sata od izlaganja nije zamijećeno potpuno vraćanje razine oštećenja DNA na kontrolne vrijednosti. Zaključeno je da je sevofluran u uvjetima pokusa bio genotoksičniji od izoflurana. Prema dobivenim rezultatima, inhalacijski anestetici koji se trenutačno koriste, sevofluran i izofluran, mogu uzrokovati oštećenja DNA u bubrežnim stanicama miša. Slični učinci mogli bi se očekivati i u ljudi, pa se ta činjenica mora uzeti u obzir u svakodnevnoj kliničkoj praksi.

KLJUČNE RIJEČI: alkalni komet test; genotoksičnost; inhalacijski anestetici; in vivo istraživanja; popravak DNA 